
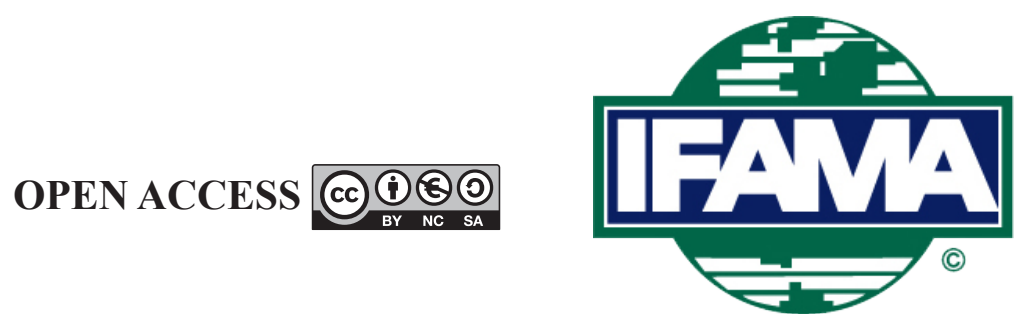

International Food and Agribusiness Management Review

Volume 23, Issue 4, 2020; DOI: 10.22434/IFAMR2019.0161

Received: 2 October 2019 / Accepted: 6 June 2020

\title{
Determinants of credit constraints for agricultural wholesalers in China \\ RESEARCH ARTICLE
}

\author{
Lifang $\mathrm{Hu}^{\oplus \mathrm{a}}$, Rigoberto A. Lopez ${ }^{\mathrm{b}}$ and Yinchu Zeng ${ }^{\mathrm{c}}$ \\ ${ }^{a}$ Assistant Professor, Capital Finance Institute, China University of \\ Political Science and Law, Beijing 100088, China P.R. \\ ${ }^{b}$ Richard DelFavero Professor, Department of Agricultural and Resource \\ Economics, University of Connecticut, Storrs, CT 06269, USA \\ 'Professor and Department Head, School of Agricultural Economics and Rural \\ Development, Renmin University of China, Beijing 100872, China P.R.
}

\begin{abstract}
Following market reforms and economic growth since the late 1970s, agricultural wholesale markets in China have developed substantially and become increasingly important in food distribution. This paper investigates the determinants of credit constraints on agricultural wholesalers. A probit model with sample selection is estimated for credit constraints and demand using data collected via a nationwide survey of 1,422 agricultural wholesalers, of whom approximately $39 \%$ were designated as credit-constrained. Empirical results confirm that an absence of relatives in the business supports the notion of further discouraging potential borrowers from applying for credit in the first place. Moreover, the probability of being credit-constrained is significantly lower for legal corporations, wholesalers who have higher-value capital assets, larger-sized wholesalers, and those in a better micro-finance environment. Some policy implications are outlined.
\end{abstract}

Keywords: agricultural market, wholesaler, credit constraint, self-rationing JEL code: Q14, Q13, O13

\footnotetext{
(i)Corresponding author: lilyruc@126.com
} 


\section{Introduction}

Credit access has implications for agricultural supply chains in developing countries (Fafchamps et al., 2003), where credit markets are thought to be immature (McKinnon, 1973; Shaw, 1973). However, previous work on agricultural credit has generally focused on the farm level (for example, Alem and Elias, 2018; Ali et al., 2014; Boucher et al., 2009; Briggeman et al., 2009; Zhao and Barry, 2014), side-stepping the existence and determinants of credit constraints faced by agricultural wholesalers. Credit constraint is a significant obstacle to capital accumulation, technology adoption, and productivity for small and medium-sized businesses (SMEs) and farm households (Akoten et al., 2006; Banerjee and Duflo, 2014; Briggeman et al., 2009; Carter and Olinto, 2003; Hu et al., 2019; Kersten et al., 2017; Narayanan, 2016). ${ }^{1}$

Chinese agricultural wholesalers, an economically important component of the food supply chain, provide a useful case study for analysis of credit access. As in many developing countries, most agricultural wholesalers in China are SMEs that play an important role in stimulating vertical market transactions and improving farmers' income and consumer welfare, as well as ensuring the food supply (Ministry of Commerce of China, 2014; Yu et al., 2009). ${ }^{2}$ More than $70 \%$ of fresh produce now passes through wholesale markets before reaching the Chinese consumer (Ministry of Commerce of China, 2014). Primary produce wholesalers are vital to downstream businesses that retail food to Chinese consumers. In addition, wholesale markets are broadly important in the Chinese economy. At the end of 2013 there were 4,476 agricultural wholesale markets in China with total annual sales of \$614 billion USD, employing 2.13 million agricultural workers and 6.5 million additional employees (Ministry of Commerce of China, 2014). It is worth noting that the People's Republic of China is the world's largest importer, producer, and consumer of agricultural products. Therefore, Chinese agricultural wholesalers' credit access can have implications for other countries.

Although there is little survey-based empirical evidence on the credit constraints of agricultural wholesalers, existing studies on SMEs and farm households offer several approaches for analyzing this issue. Credit constraints arise from both screening on the supply side and 'self-rationing' on the demand side. ${ }^{3}$ Most existing rigorous micro-econometric studies have analyzed credit constraints from the supply side, paying little attention to analysis from the demand side. Akoten et al. (2006) adopted probit models to estimate the factors affecting access to credit from friends and relatives, rotating savings, and credit associations (ROSCAs), micro-finance institutions, and banks, respectively, by garment producers in three garment clusters in Kenya that sell their products to traders or consumers. They found that the characteristics of both the operation and the owner influence garment producers' access to different credit sources, and that old firms and firms having more relatives in the same line of business (i.e. socially networked) have better access to subsidized bank loans. Akoten et al. (2006) explained the results from the perspective of banks, because lending to experienced borrowers can reduce the chances of business failure and increase the likelihood of repayment. In addition, banks may base loan decisions on the reputation and the social network of borrowers, such as ROSCAs and other informal credit sources that are organized by insiders. Briggeman et al. (2009), using a weighted logit model, demonstrated that having greater net worth and being in business longer lower the probability of farms' being credit-constrained. As for non-farm proprietorships, having greater net worth, more employees, and more liquidity lowers their probability of being constrained; and businesses with operators having a college education are more likely to get access to credit in both models.

\footnotetext{
${ }^{1}$ Credit constraints arise from the asymmetry of information between the lender and the borrower. The potential for adverse selection and breaches of contracts discourage lenders from using the interest rate to ration excess credit demand (Stiglitz and Weiss, 1981). As a result, some borrowers may receive credit, while others with similar financial characteristics may not (Briggeman et al., 2009).

2 In developing countries, agricultural wholesalers, also called intermediaries or brokers, play an active role in connecting smallholders with processors, retailers, and consumers (Fafchamps and Minten, 1999; Fafchamps et al., 2003; Gabre-Madhin, 2001).

3 Jappelli (1990), Crook (1996), and Petrick (2004) identify a household as credit-constrained if its demand for credit exceeds the supply of credit, while Jappelli (1990) and Cox and Jappelli (1993) identified 'discouraged borrowers' as those who didn't apply for credit for fear of being denied, and Kon and Storey (2003) and Zhao and Barry (2014) found that high application costs and banks' erroneous screening due to lack of information could discourage applicants. Thus, applicants who do not get correct information about the credit market would probably forgo applying. Such 'self-rationing' from the demand side is more related to potential borrowers' choices and is different from credit rationing from the supply side.
} 
How to measure credit constraints is also a much-debated issue. According to Jappelli (1990), Cox and Jappelli (1993), Crook (1996) and Petrick (2004), a potential borrower is defined as credit-constrained if he or she is in one of the following three classes: (1) the application was denied by lenders; (2) the loan amount offered by the lenders was less than the borrower's demand for credit; (3) the potential borrower did not apply for credit because of a fear of denial. A potential borrower in other situations is classified as not credit-constrained. Briggeman et al. (2009) pointed out that there is a contamination of the control group in the above classification, because those who did not need credit and those who were treated as creditconstrained but later received credit are classified as not credit-constrained.

The objective of this study is thus to document the extent to which Chinese agricultural wholesalers are credit-constrained and, if so, to identify key determinants behind those constraints. The main conclusions of this study are derived from the empirical analysis of nationwide survey data on agricultural wholesalers in China. First, approximately $39 \%$ of agricultural wholesalers are credit-constrained. Second, the probability of agricultural wholesalers being credit-constrained is affected by factors from both the supply and demand sides. From the supply side, wholesalers are more likely to be credit-constrained when: (1) they operate as a non-corporation; and (2) they have less collateral to back up the loans. From the demand side, wholesalers are more likely to be discouraged from applying for loans when: (1) their operations are relatively small; and (2) their effective application cost is high, which is posited as depending on lack of access to social networks.

Key contributions of this paper are: (1) The analysis of the causes of formal credit constraints arising from both the formal rationing by commercial banks and self-rationing by wholesalers. This framework is more precise than only analyzing the determinants of credit constraints from the supply side. (2) We adopt a probit model with sample selection to estimate factors affecting the probability of being credit-constrained, using two steps to determine whether or not a wholesaler is credit-constrained: determining whether or not a wholesaler has demand for credit; and if so, whether that wholesaler is credit-constrained. This approach can eliminate contamination from those who do not need credit being in the control group and further avoid sample selection bias by applying a probit model with sample selection rather than an ordinary probit or logit model, as is done in many existing studies. (3) The results of this study shed light on lack of evidence on Chinese agricultural wholesalers' access to credit and its determinants. Because China is the world's largest producer, consumer, and importer of agricultural products, the functioning of Chinese markets is of interest for their effect on world markets. Identifying determinants of credit constraints faced by smallersized operations that are non-corporations and lack access to social networks is challenging, and policy interventions could be designed to address these credit constraints.

\section{Conceptual analysis}

Theoretical frameworks developed by Stiglitz and Weiss (1981) and Kon and Storey (2003) offer ways to conceptualize the loan decisions of commercial banks and the borrowing decisions of agricultural wholesalers. First, the characteristics of the business operation and the owner are $Z^{b}$ and $Z^{h}$, respectively. The revenue without borrowing is $\pi\left(K, L ; Z^{b}, Z^{h}\right)$, where $K$ and $L$ denote the capital and labor inputs. Second, the interest rate is $I$, and the value of collateral is $A$. The application cost is $C$. Third, if a wholesaler finances the business through formal loans, the return on being successful is $\varphi_{s}$, with a probability of $p$, while the return on failure is $\varphi_{f}$, with a probability of $1-p$, and $\varphi_{f}<\pi<\varphi_{s}$.

\subsection{Credit rationing from the supply side}

The asymmetry of information between the supply side and the demand side of the credit market discourages lenders from using the interest rate to ration credit. That is, if the lender raises the interest rate, the distribution of the borrowers' repayment probabilities will change because of adverse selection, resulting in increasing risk of breaches. In order to eliminate excess demand for credit and achieve market equilibrium, commercial banks generally adopt other methods to ration credit (Stiglitz and Weiss, 1981). Since commercial banks do 
not use interest rates as an indicator in screening potential borrowers, what are the crucial factors affecting their decisions on credit?

To enforce repayment by borrowers who have potential for defaulting, banks and micro-finance institutions may require additional observable information, such as operation status of the business and owners' managerial ability (Akoten et al., 2006; Briggeman et al. 2009; Olomola, 2014). Classifying agricultural wholesalers as corporations or non-corporations permits analysis of which kind of business is more likely to succeed and make repayment. Corporations generally manage business and risk aversion better than non-corporations, so lenders may prefer offering credit to corporations. Although a corporation's debts are legally limited liabilities, lenders often require mortgages, for example, on the owners' houses, when serving small businesses (Berkowitz and White, 2004). In practice, then, the owners of a corporation are also responsible for its debts. Thus, lending to corporations reduces the possibility of business failure and breaches of the loan contract, which is a good method to increase the possibility of repayment $p$ by the borrowers.

Since the lender does not increase the interest rate $I$ as a tool to screen potential borrowers, the expected return will depend on the repayment possibility $p$ and the collateral value $A$. It seems that the value of mortgage collateral is a determinant factor of lenders' decisions. Borrowers with a shortage of collateral are less likely to obtain loans. However, Stiglitz and Weiss (1981) further illustrated that the impact of collateral may be similar to that of interest, because borrowers with high-value collateral may be less risk-averse and invest projects with high risks.

\subsection{Self-rationing from the demand side}

We draw our analysis from Kon and Storey's (2003) theory in which an agricultural wholesaler's decision to borrow is based on the following.

$$
t\left[\varphi_{s} p+\left(\varphi_{f}-A\right)(1-p)-C-I\right]+(1-t)(\pi-C)>\pi
$$

Therefore,

$$
\begin{aligned}
& \varphi_{s} p+\left(\varphi_{f}-A\right)(1-p)>C / t+I+\pi \\
& F=C / t+I+\pi
\end{aligned}
$$

Considering that financial institutions implement imperfect screening of applicants, the possibility of applicants with same qualifications getting a loan is $t$, and $0<t<1$, where $t$ denotes the probability that a financial institution properly accepts the qualified (good) borrowers, reflecting the level of perfect screening by the financial institution. This situation of credit rationing by financial institutions was also mentioned by Briggeman et al. (2009) and Zhao and Barry (2014).

Kon and Storey (2003) defined 'the effective borrowing cost' $F$ as the sum of the application cost $C / t$, interest payment $I$, and the opportunity $\operatorname{cost} \pi$. According to Equation 2, if the effective borrowing cost is too high, it will be difficult for a wholesaler to obtain the expected net return, resulting in a situation of credit constraint: potential borrowers do not apply for credit because they cannot afford the expected cost of the loan, which is a self-rationing behavior. A potential borrower in this situation is defined as a discouraged borrower (Cox and Jappelli, 1993; Jappelli, 1990; Kon and Storey, 2003).

First, compared to a situation with perfect screening by the financial institution, the potential borrower is more likely to be discouraged. The higher the perfect screening level $t$, the smaller the $F$; agricultural wholesalers are more likely to borrow when $t$ is high. Thus, the imperfect screening of applicants on the supply side may result in self-rationing by further increasing potential borrowers' expected costs. 
Second, the application $\operatorname{cost} C$ is a determinant factor of the real application $\cos t C / t$, which varies across wholesalers. Especially in Chinese credit markets, the application cost $C$ is highly dependent on the applicant's social capital; if we include these implicit costs, socially networked wholesalers may be charged less during the process of loan application and have more access to credit. In addition, because financial institutions do not use the interest rate as way to ration credit, one can assume that agricultural wholesalers face the same interest rate $I$, leading to the conclusion that the lower the application cost and the more perfect the screening of applicants by financial institutions, the lower the probability of the agricultural wholesaler's being credit-constrained as a result of being less discouraged.

Kon and Storey (2003) pointed out that if the cost of applying for a loan is $C=0$, then Equation 2 will be $\varphi_{s} p+\varphi_{f}(1-p)>I+\pi$. Thus, an agricultural wholesaler's decision on borrowing will only be subject to the expected net return of the project and opportunity cost; it will not be affected by the imperfect screening of applicants by the financial institution that results from asymmetry of information. In this case, because no discouragement results from imperfect screening, we can only estimate discouragement of borrowing in the credit market with positive application costs.

\subsection{Propositions}

From the preceding, given that credit constraints can arise from the supply side by rejecting applications or through the demand side by discouraging borrowing, the following propositions are made:

Proposition 1: agricultural wholesalers who operate as corporations are less likely to be creditconstrained than wholesalers who are self-employed or operate in partnership with other wholesalers.

Proposition 2: agricultural wholesalers with less collateral are less likely to obtain a loan and, thus, more likely to be credit-constrained.

Proposition 3: smaller-sized agricultural wholesalers will be more likely to be discouraged from applying for a loan given the relatively large application cost and, thus, more likely to be creditconstrained.

Proposition 4: wholesalers exposed to increased information will lower the effective application cost and, thus, be less discouraged from applying for a loan and less likely to be credit-constrained.

The first two propositions are based on the theory of credit rationing from the supply side and the last two propositions are based on self-rationing or discouragement from the demand side. We propose the following empirical model of credit constraints and demand to test these propositions and to identify key drivers that affect credit constraints and demand.

\section{Empirical model}

Briggeman et al. (2009) observed that there is a contamination in Jappelli (1990)'s classification of credit constraints arising from estimation bias when potential borrowers who no longer need credit are directly classified into the control group. Based on the above analysis, estimation of a wholesaler's state of credit constraint can be divided into two steps: determining whether or not (1) an agricultural wholesaler has demand for credit; and (2) if so, whether that wholesaler is credit-constrained.

\subsection{Credit demand model}

First, the probit equation modeling credit demand by agricultural wholesalers is expressed as:

$$
D_{i}=X_{i j} \beta_{j}+R_{i n} \theta_{n}+\varepsilon_{i}
$$


where $i$ denotes a particular wholesaling operation, $j$ denotes a characteristic associated with that wholesaler, and $n$ denotes a geographic region where the wholesaler operates. $D_{i}$ is a binary variable modeling credit demand by the agricultural wholesaler, where $D_{i}=1$ indicates if a wholesaler demands credit; and $D_{i}=0$ otherwise. $X_{i j}$ is a vector of exogenous variables that includes business and the wholesaler's personal characteristics. The terms $\beta_{j}$ and $\theta_{n}$ are parameters to be estimated. $R_{i n}$ is a vector of regional fixed effects. The error term is denoted by $\varepsilon_{i}$, assumed to be distributed as $\varepsilon_{i} \sim N\left(0, \sigma_{\varepsilon}^{2}\right)$.

\subsection{Credit constraint model}

If an agricultural wholesaler is seeking credit (i.e. has a positive demand for credit), we identify their status of credit constraint in the second stage. To this end, the following model is considered:

$$
C_{k}=Y_{k m} \delta_{m}+R_{k n} \varphi_{n}+\mu_{k}
$$

where $k=i$ if $D_{i}=1$, otherwise the wholesaler is not included in the sample. $C_{k}$ is a binary variable denoting the status of credit constraint where $C_{k}=1$ if the wholesaler is credit-constrained; $C_{k}=0$ otherwise. $Y_{k m}$ is a vector of exogenous variables of business and the wholesaler's personal characteristics associated with credit constraints, and $R_{k n}$ denotes a regional dummy variable where the wholesaler operates. The terms $\delta_{m}$ and $\varphi_{n}$ denote parameters to be estimated. The error term is denoted by $\mu_{k}$, assumed to be distributed as $\mu_{k}$ $\sim N\left(0, \sigma_{\mu}^{2}\right)$.

There are at least two methods to estimate Equations 4 and 5: the first is to estimate these equations separately as ordinary probit models; the second is the probit model with sample selection that combines the equations (Van de Ven and Van Praag, 1981), where Equation 4 is the selection model, and Equation 5 is the main equation model. There should be $\left(\varepsilon_{i}, \mu_{i}\right) \sim N\left(0,0, \sigma_{\varepsilon}^{2}, \sigma_{\mu}^{2}, \rho\right)$ for estimating Equation 4 and 5 by probit model with sample selection. Specifically, the probit model with sample selection estimates the correlation coefficient $\rho$ between the error terms of the two models and the significance of $\rho=0$. Therefore, if the results can reject the null hypothesis of no sample selection, the following discussion of credit constraint will be based on the estimation results of the probit model with sample selection; otherwise, it will be based on the estimation results of ordinary probit models.

\section{Data and model specification}

Because economic and credit data on agricultural wholesalers in China is lacking, primary data collection was necessary. The data used is from a national survey administered in 18 agricultural wholesale markets in 13 provinces in China from October through December 2014. It comprises 1,422 agricultural wholesalers in total. ${ }^{4}$

Data collected included trading volume, annual turnover, geographical location, and credit access information, as well as other essential business information from the Ministry of Commerce of China (Ministry of Commerce of China, 2014). Ten to 40 wholesalers were randomly selected from sub-markets for vegetables, fruits, meat, grain, oil, fish, flowers, tea and other business categories, with the number of categories differing depending on the wholesale market. Altogether, this data provides comprehensive information on wholesalers' access to and use of different sources of credit, as well as indicators of the businesses and the demographic characteristics of the owners.

\footnotetext{
${ }^{4}$ The original sample included 1,601 wholesalers. After deleting the those with missing data for credit demand, credit access, operating characteristics, and the characteristics of the owners, the final estimation sample in this study contains 1,422 agricultural wholesalers. The survey was conducted by School of Agricultural Economics and Rural Development, Renmin University of China.
} 


\subsection{Credit constraints}

Among those who applied for credit in the last two years, wholesalers who reported that they applied through commercial banks or micro-finance institutions but were rejected or only got part of what they applied for are classified as credit-constrained; wholesalers who applied for the loans and obtained the total amount they applied for are classified as not credit-constrained. Second, from the wholesalers who did not apply for credit during the last two years, we observe the discouraged borrowers' self-rationing behaviors and classify those individuals as credit-constrained.

Of the 1,422 wholesalers in the sample, 526 wholesalers expressed that they had credit demand. Of these, credit-constrained wholesalers were classified into borrowers rationed by financial institutions and discouraged borrowers. As indicated in Table 1, approximately 39\% of those who had credit demand are considered credit-constrained. It is interesting to note that the wholesalers who were discouraged from applying number about twice as many as those who actually applied and were rejected by the financial institutions. This calls to attention that a key factor in credit constraints is discouragement of potential borrowers even though they needed credit.

\subsection{Other explanatory variables}

Next, we describe the characteristics of the owners in Table 1 . More than $40 \%$ of the wholesalers in the sample have formal education degrees (high school and college degrees). Male owners account for $74.3 \%$ of the sample, and owners' ages vary from 18 to 74 years, with a mean of 38.65, and married owners account for $87.2 \%$. The means and standard deviations of the owner characteristics for both credit-demanding and credit-constrained wholesalers have no significant differences from those of the whole sample. In addition, to control for the geographical location of the agricultural wholesalers, we added regional fixed effects. Using Central China as the benchmark region, we include two regional fixed effects in the regression to capture

Table 1. Prevalence of credit constraints among agricultural wholesalers.

\begin{tabular}{|c|c|c|c|}
\hline Subgroups & Self-reported reasons & $\begin{array}{l}\text { Number of } \\
\text { obs. }\end{array}$ & $\begin{array}{l}\text { Percentage (among those } \\
\text { who needed credit) }\end{array}$ \\
\hline Demanded credit & Applied or wished to apply for credit & 526 & $100 . \%$ \\
\hline \multirow{2}{*}{$\begin{array}{l}\text { Rationed by financial } \\
\text { institutions }\end{array}$} & I applied but was rejected. & 17 & $12.74 \%$ \\
\hline & $\begin{array}{l}\text { The amount was only part of the amount } \\
\text { applied. }\end{array}$ & 50 & \\
\hline \multirow{8}{*}{$\begin{array}{l}\text { Discouraged (needed but } \\
\text { did not apply for credit) }\end{array}$} & I am in fear of denial. & 62 & $26.04 \%$ \\
\hline & $\begin{array}{l}\text { The loan application procedure is too } \\
\text { complicated. }\end{array}$ & 44 & \\
\hline & The interest rate is too high. & 13 & \\
\hline & I am not familiar with bankers. & 8 & \\
\hline & The loan term or amount is inappropriate. & 5 & \\
\hline & I lack collateral. & 2 & \\
\hline & $\begin{array}{l}\text { I fear that I have no chance of success in } \\
\text { business and can't make repayment. }\end{array}$ & 2 & \\
\hline & $\begin{array}{l}\text { I am not local citizen and am afraid of } \\
\text { being rejected. }\end{array}$ & 1 & \\
\hline Total & & 204 & $38.8 \%$ \\
\hline
\end{tabular}


financial environment and other unobserved regional effects: East and West China, ${ }^{5}$ The business and owner characteristics of wholesale operations to estimate Equations 5 and 6 are shown in Table 2.

According to Olomola (2014), credit demand is affected by the characteristics of the business and the owner. In this paper, the following variables indicate the characteristics of the business: organization status (corporation or non-corporation), features of business activities (firm size, having long-term employees, years in business, etc.), and business categories (vegetable, fruit, meat, grain, etc.). Level of education, gender, age, and marital status denote the characteristics of the owner.

In accordance with the above propositions, being a corporation, the value of mortgage assets, firm size, the cost of loan application, and the screening mechanisms of financial institutions may affect the state of credit constraint of agricultural wholesalers. Due to the absence of data on application costs and screening mechanisms of financial institutions for those wholesalers who did not apply for credit, we need to select suitable proxies for these two dimensions based on the answers in the questionnaire.

First, the variables self-employed wholesalers and partnerships permit comparison with corporations. Second, the value of fixed assets and having purchased local houses are the indicators of collateral.

Third, using annual turnover as an explanatory variable of firm size introduces endogeneity, as access to credit can have a significant impact on the performance of agricultural supply chains (Banerjee and Duflo, 2014; Briggeman et al., 2009; Kersten et al., 2017; Narayanan, 2016). Instead, we use a dummy variable rather than annual turnover to denote firm size, and wholesalers are categorized by micro and small-sized, and medium and large-sized. ${ }^{6}$ However, this does not guarantee completely avoiding endogeneity problems beyond the sample selection bias.

Fourth, because the application cost referred to in the theoretical model mainly arises from the process of seeking information and preparing the application materials in order to apply for the loan successfully, when credit is a limited resource that cannot meet the total demand, social capital can help wholesalers build their reputation, speed up the information search, and pay fewer additional fees. Following this rationale, the number of relatives and friends in the same line of business serves as a proxy for social capital to denote the application cost.

Last, the wholesalers' satisfaction with financial services in the micro-finance environment can reflect the degree of information asymmetry to some extent, and it is also a mirror of the degree of the imperfect screening of applicants by financial institutions. As mentioned by Kon and Storey (2003) and Briggeman et al. (2009), in the situation of imperfect screening, some applicants will receive credit, but some applicants with similar financial characteristics will not. With a better environment for financing in the wholesale markets, banks are more likely to obtain more detailed information about borrowers' operations, and wholesalers are more likely to be familiar with the loan application process, which can result in reduced information asymmetry and better screening mechanisms by banks. Therefore, in this article, wholesalers' satisfaction with financial services serves as the proxy for the degree of perfection of the screening mechanisms of financial institutions. In addition to the above variables, we further control for wholesalers' business categories (vegetable, fruit, meat, grain, etc.), as well as characteristics of owners (education, gender, age, marital status) in the empirical model.

To begin, given the magnitude of wholesalers' business, the mean of total sales in 2013 is 19.08 million yuan (i.e. \$3.129 million USD) for the overall sample, and micro and small-sized wholesalers account for $51.8 \%$.

\footnotetext{
5 The East China region includes the following provinces: Beijing, Shandong, Jiangsu, Shanghai, Zhejiang, Guangdong and Liaoning. The Central China region includes Henan and Hubei. The West China region includes Shaanxi, Sichuan, Yunnan and Inner Mongolia.

${ }^{6}$ According to the firm size classification for the agricultural industry issued by the Ministry of Commerce of China, an agricultural firm with annual sales lower than 0.5 million yuan per year is a micro-firm; those with annual sales between 0.5 million and 5 million yuan are small firms; those with sales between 5 million and 200 million yuan are medium-sized firms; and those with sales more than 200 million yuan are designated as large firms.
} 
Table 2. Summary statistics. ${ }^{1}$

\begin{tabular}{|c|c|c|c|c|c|c|c|}
\hline \multicolumn{2}{|l|}{ Descriptive statistics } & \multicolumn{2}{|c|}{ Total $=1$} & \multicolumn{2}{|c|}{ Demand=1 } & \multicolumn{2}{|c|}{ Constraint $=1$} \\
\hline \multicolumn{2}{|l|}{ Sample size } & \multicolumn{2}{|l|}{1,422} & \multicolumn{2}{|l|}{526} & \multicolumn{2}{|l|}{204} \\
\hline Variables & Explanation & Mean & SD & Mean & SD & Mean & SD \\
\hline Demand & having demand for credit $=1$; otherwise $=0$ & 0.370 & 0.483 & 1 & 0 & 1 & 0 \\
\hline Credit constraint & credit-constrained $=1 ;$ otherwise $=0$ & 0.388 & 0.488 & 0.388 & 0.488 & 1 & 0 \\
\hline \multicolumn{8}{|l|}{ Business } \\
\hline Self-employed & self-employed $=1$; otherwise $=0$ & 0.587 & 0.493 & 0.565 & 0.496 & 0.583 & 0.494 \\
\hline Partnership & partnership $=1$; otherwise $=0$ & 0.257 & 0.437 & 0.247 & 0.432 & 0.270 & 0.445 \\
\hline Capital assets $^{2}$ & Value of fixed assets (million yuan) & 0.480 & 1.699 & 0.505 & 1.410 & 0.292 & 0.711 \\
\hline Apartment owner & $\begin{array}{l}\text { Own houses or apartment }=1 \text {; } \\
\text { otherwise }=0\end{array}$ & 0.360 & 0.480 & 0.384 & 0.487 & 0.299 & 0.459 \\
\hline Relatives & $\begin{array}{l}\text { number of relatives and friends in the } \\
\text { same line of business }\end{array}$ & 23.59 & 274.7 & 14.81 & 29.82 & 11.78 & 18.62 \\
\hline Financial service & financial service assessment ${ }^{3}$ & 2.933 & 0.927 & 2.876 & 1.026 & 2.721 & 1.010 \\
\hline $\begin{array}{l}\text { Micro and small- } \\
\text { sized }\end{array}$ & micro and small-sized $=1$; otherwise $=0$ & 0.518 & 0.500 & 0.477 & 0.500 & 0.515 & 0.501 \\
\hline Employment & $\begin{array}{l}\text { having long-term employees }=1 \text {; } \\
\text { otherwise }=0\end{array}$ & 0.496 & 0.500 & 0.542 & 0.499 & 0.529 & 0.500 \\
\hline Firm's age & years in business & 11.27 & 7.450 & 11.85 & 7.525 & 11.69 & 7.631 \\
\hline Supplier & $\begin{array}{l}\text { having long-term suppliers }=1 \text {; } \\
\text { otherwise }=0\end{array}$ & 0.696 & 0.460 & 0.719 & 0.450 & 0.745 & 0.437 \\
\hline \multicolumn{8}{|l|}{ Ag category } \\
\hline Vegetable wholesaler & $\begin{array}{l}\text { belongs to vegetable market }=1 \text {; } \\
\text { otherwise }=0\end{array}$ & 0.390 & 0.488 & 0.327 & 0.470 & 0.348 & 0.478 \\
\hline Fruit wholesaler & belongs to fruit market $=1$; otherwise $=0$ & 0.187 & 0.390 & 0.234 & 0.424 & 0.275 & 0.447 \\
\hline Meat wholesaler & belongs to meat market $=1$; otherwise $=0$ & 0.065 & 0.246 & 0.059 & 0.236 & 0.044 & 0.206 \\
\hline Grain wholesaler & belongs to grain market $=1$; otherwise $=0$ & 0.073 & 0.260 & 0.097 & 0.296 & 0.064 & 0.245 \\
\hline Miscellaneous $^{4}$ & $\begin{array}{l}\text { belongs to other markets except } \\
\text { vegetable, fruit, meat and grain } \\
\text { markets }=1 \text {; otherwise }=0\end{array}$ & 0.285 & 0.451 & 0.283 & 0.451 & 0.270 & 0.445 \\
\hline \multicolumn{8}{|c|}{$e_{1}$} \\
\hline Formal education 5 & $\begin{array}{l}\text { high school or college education }=1 \text {; } \\
\text { otherwise }=0\end{array}$ & 0.402 & 0.491 & 0.414 & 0.493 & 0.402 & 0.492 \\
\hline Male & male $=1$; otherwise $=0$ & 0.743 & 0.437 & 0.745 & 0.436 & 0.716 & 0.452 \\
\hline Owner's age & owner's age & 38.65 & 9.850 & 38.83 & 9.622 & 38.59 & 9.460 \\
\hline Married & married $=1$; otherwise $=0$ & 0.872 & 0.334 & 0.876 & 0.329 & 0.873 & 0.334 \\
\hline \multicolumn{8}{|l|}{ Region 6} \\
\hline East region & located in eastern China & 0.536 & 0.499 & 0.428 & 0.495 & 0.392 & 0.489 \\
\hline Central region & located in central China & 0.152 & 0.359 & 0.202 & 0.402 & 0.191 & 0.394 \\
\hline West region & located in western China & 0.312 & 0.464 & 0.371 & 0.483 & 0.417 & 0.494 \\
\hline
\end{tabular}

${ }^{1} \mathrm{SD}=$ standard deviation.

2 The explanatory variable 'capital assets' refers to the present value of fixed assets that the wholesalers own for selling agricultural products, including trucks, packing and processing machines, weighing facilities, communication equipment, cold storage warehouses, and stalls.

${ }^{3}$ Financial service assessment: very good=5; good=4; fair=3; bad=2; very bad $=1$.

${ }^{4}$ Miscellaneous includes oil, fish, flowers, tea, and other markets, except vegetable, fruit, meat and grain markets. This category was used as a fixed effect benchmark.

${ }^{5}$ Education level: the benchmark of education is informal education (less than high school degree). College degree includes college and junior college degree levels.

${ }^{6}$ The benchmark for regional fixed effects is Central China. The East, Central, and West China regions include 712, 216, and 444 observations, respectively. 
The percentage of wholesalers having long-term employees among those demanding credit is $54.2 \%$, which is slightly higher than that of the overall sample. Second, the mean of operating years of the overall sample is 11.27, which coincides with the fact that agricultural distribution is highly dependent on family heritage. Third, self-employed wholesalers and partnerships account for 58.7 and $25.7 \%$, respectively, of the overall sample; that is, non-corporations make up $84.4 \%$ of the whole sample. This suggests that, among Chinese agricultural wholesalers, the most common organizational status is non-corporation and that most noncorporations are self-employed households. Fourth, the value of fixed assets that can be used as collateral and social capital that can reduce application costs vary considerably among wholesalers.

\section{Empirical results}

Regression results of the probit model with sample selection, using Stata 12.0 (StataCorp LLC, College Station, TX, USA), are shown in Table 3. The tests reject the null hypothesis of no sample selection. Therefore, the following discussion of the credit constraints of agricultural wholesalers is based on the results of the probit model with sample selection. Table 3 shows that the coefficients of the variables organizational status, value of fixed assets, house or apartment ownership, social networks, and financing services are statistically significant, which generally accords with expectations and confirms the propositions.

Table 3. Estimation results for credit constraints and demand. ${ }^{1}$

\begin{tabular}{|c|c|c|c|c|}
\hline & \multicolumn{4}{|c|}{ Probit model with sample selection } \\
\hline & \multicolumn{2}{|c|}{ Constraint } & \multicolumn{2}{|l|}{ Demand } \\
\hline & Coef. & Std. Err. & Coef. & Std. Err. \\
\hline \multicolumn{5}{|l|}{ Business } \\
\hline Self-employed & $0.208^{* *}$ & 0.096 & $-0.167^{* *}$ & 0.085 \\
\hline Partnership & $0.223^{*}$ & 0.118 & $-0.184^{*}$ & 0.105 \\
\hline Capital assets & $-0.074^{* *}$ & 0.030 & & \\
\hline Apartment owner & $-0.194^{* * *}$ & 0.059 & & \\
\hline Relatives & $-0.003^{* *}$ & 0.001 & & \\
\hline Service & $-0.070^{* * *}$ & 0.027 & & \\
\hline Micro and small-sized & $0.138^{*}$ & 0.076 & -0.107 & 0.070 \\
\hline Employment & & & $0.139^{* * *}$ & 0.052 \\
\hline Firm's age & & & $0.008^{*}$ & 0.004 \\
\hline Supplier & & & $0.097^{*}$ & 0.051 \\
\hline \multicolumn{5}{|l|}{ Ag category } \\
\hline Vegetable wholesaler & 0.135 & 0.100 & 0.010 & 0.090 \\
\hline Fruit wholesaler & -0.088 & 0.113 & $0.287^{* * *}$ & 0.103 \\
\hline Meat wholesaler & -0.113 & 0.120 & -0.004 & 0.106 \\
\hline Grain wholesaler & $-0.369^{* *}$ & 0.151 & $0.307^{* *}$ & 0.143 \\
\hline \multicolumn{5}{|l|}{ Owner } \\
\hline Formal education & -0.022 & 0.077 & -0.035 & 0.070 \\
\hline Male & -0.063 & 0.087 & -0.033 & 0.079 \\
\hline Owner's age & -0.002 & 0.004 & -0.003 & 0.004 \\
\hline Married & -0.020 & 0.110 & 0.042 & 0.100 \\
\hline \multicolumn{5}{|l|}{ Region } \\
\hline East region & 0.144 & 0.110 & $-0.490^{* * *}$ & 0.100 \\
\hline West region & 0.081 & 0.120 & -0.101 & 0.112 \\
\hline cons & $0.901^{* * *}$ & 0.243 & -0.040 & 0.208 \\
\hline $\bar{\rho}$ & -1 & & & \\
\hline Test of $\rho=0$ & \multicolumn{4}{|c|}{$\operatorname{chi}^{2}(1)=12.12^{* * *}$} \\
\hline Wald test & \multicolumn{4}{|c|}{$\operatorname{chi}^{2}(17)=76.22^{* * *}$} \\
\hline Log likelihood & \multicolumn{4}{|c|}{$-1,221.1$} \\
\hline Number of obs. & \multicolumn{4}{|l|}{1,422} \\
\hline Censored obs. & \multicolumn{4}{|l|}{896} \\
\hline Uncensored obs. & \multicolumn{4}{|l|}{526} \\
\hline
\end{tabular}

${ }^{1}$ Significance levels are denoted by $* * *, * *$ and $*$ for 1,5 and $10 \%$, respectively. 
First, self-employed households and partnerships have a higher probability of being credit-constrained compared with corporations, and the percentages of credit-constrained wholesalers are 40.1, 42.3, and 30.3 for self-employed households, partnerships, and corporations, respectively (as shown in Figure 1), indicating that the likelihood that corporations are credit-constrained is lower than that of non-corporations, thus confirming the first hypothesis. This disparity can be illustrated by the fact that corporations have a higher chance of success in business and a greater propensity to repay loans. Generally, corporations manage resource allocation and business operations, and control risk better than non-corporations, which also guarantees revenue from invested loan funds, reduces the probability of default, and makes it easier for corporations to obtain loans. In addition, commercial banks always require borrowers to provide evidence of their ownership of property, such as a house, as collateral. Thus, while a corporation can apply for bankruptcy liquidation when it cannot make repayment, a non-corporate owner is responsible for the debt. In addition, the debt liabilities of corporations are more flexible than those of the self-employed, placing the debt liabilities of corporations somewhere between limited and unlimited liabilities (Berkowitz and White, 2004). Unlike corporations, a partnership's debts are joint liabilities based on the partnership contract. In practice, it is more difficult to enforce the partners' repayment of debts in joint liabilities than personal liabilities, so partners have more incentives to breach their contracts. Thus, lenders are more likely to deny a partnership's application for credit. Based on the above two points, the possibility of a corporation's being credit-constrained is less than that of a non-corporation.

Second, wholesalers having more capital assets that can be treated as collateral are less likely to be creditconstrained, which is in line with findings of Akoten et al. (2006) and Briggeman et al. (2009). The percentages of credit-constrained wholesalers in different capital asset categories are shown in Figure 2. Under the same conditions, financial institutions would favor wholesalers who have high-value collateral, and the value of collateral indirectly affects the amount a borrower can obtain, that is, to what extent the borrower is credit-constrained. However, in the distribution industry, most businesses lack collateral. Wholesalers selling agricultural products that need processing or storage generally use fixed facilities, such as packing machines and cold storehouses, which are probably rented from the wholesale markets. For instance, wholesalers having storage facilities constitute $40.99 \%$ of the 1,422 wholesalers, but their storage facilities vary considerably and include normal trucks, cold trucks, and cold storehouses. Many of these wholesalers lack or have limited access to collateral.

Third, firm size has negative impacts on the possibility of being significantly credit-constrained. The state of credit constraints varies among wholesalers of different sizes. The results reveal that for micro, small, medium, and large firms, the percentages of credit-constrained wholesalers are 54, 38.8, 36.1, and 33.3, respectively (as shown in Figure 3). The results showing that the percentage of credit-constrained small wholesalers is higher than that of large wholesalers merit additional illustration of the incidence of credit constraints with respect to the size of wholesalers, particularly in terms of discouragement to apply for loans, as pointed out by Kon and Storey (2003). Given the relatively high application and transaction costs, smaller agricultural wholesalers will be more likely to be discouraged from applying for a loan and, therefore, more likely to be credit-constrained.

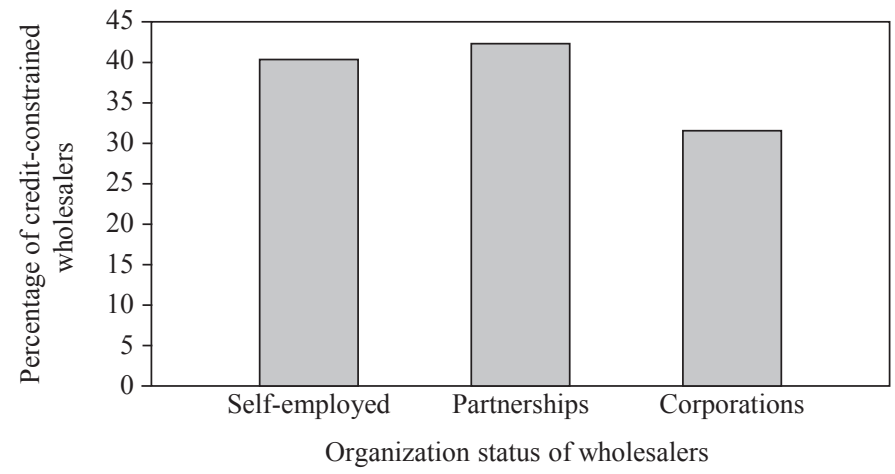

Figure 1. Percentage of credit-constrained wholesalers by legal form of business. 


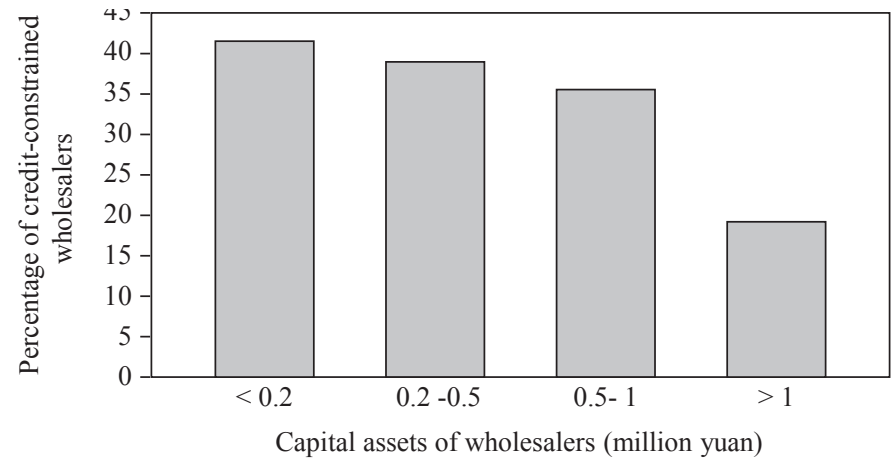

Figure 2. Percentage of credit-constrained wholesalers by size of capital assets.

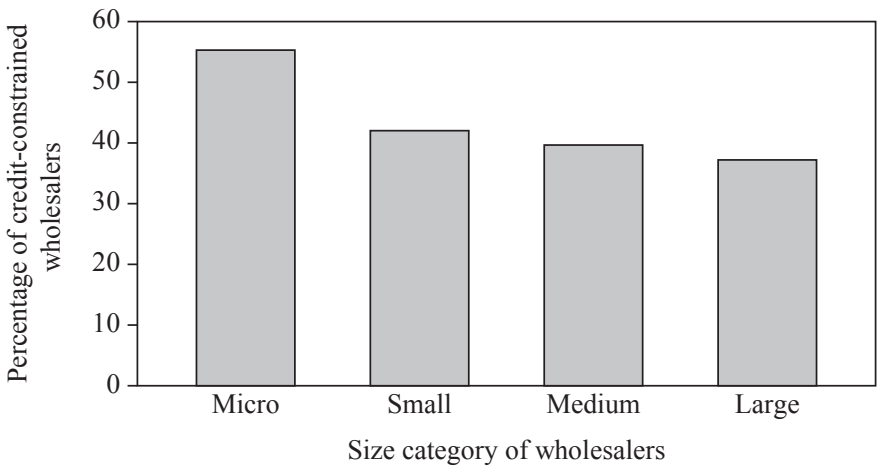

Figure 3. Percentage of credit-constrained wholesalers by size. Size categories are defined in million yuan of sales.

Fourth, social network and financing services have negative impacts on the possibility of being creditconstrained. The negative signs of the two factors imply that social capital and financing services are important for wholesalers' access to credit. On one hand, having more acquaintances and social relationships means having a higher endowment of social capital. Social capital exposes potential borrowers to more loan information (Gao et al., 2019), resulting in less information asymmetry between borrowers and lenders, and these wholesalers are more likely to pay fewer 'additional costs' when applying for loans. As mentioned in the discussion of the econometric model, a wholesaler's expected net return will increase by reducing the application cost, thus increasing their confidence in borrowing decisions, which lowers the possibility of self-rationing. In practice, the additional cost required by financial institutions delivers the market signal to potential borrowers that 'borrowing is difficult.' In this case, when a wholesaler requires credit, they probably make the borrowing decision through or with acquaintances who have loan experiences and can help provide more information. On the other hand, due to the long-existing credit rationing in Chinese financial markets, financial institutions have a relatively high probability of imperfect screening, which deepens the feeling that 'borrowing is difficult' and discourages some potential borrowers. For instance, the 'discouraged borrowers' make up as much as $26 \%$ of the group seeking loans and two-thirds of those who are credit-constrained.

Last, the variables relevant to the characteristics of owners, such as education level, gender, age, and marital status, do not have significant impacts on credit constraints. Education level is an important measure of human capital and reflects wholesalers' management capabilities to some extent, however, and it probably has a positive impact on access to loans. 


\section{Conclusions}

The majority of agricultural wholesalers in China are SMEs. Like other SMEs, agricultural wholesalers are more likely to face credit constraints. The findings reported in this paper show that the formal credit constraints of agricultural wholesalers are the result of 'double rationing': screening decisions by financial institutions and self-rationing by discouraged borrowers. These results differ from those of previous studies that focused only on credit rationing from the supply side.

This article has several salient conclusions based on the conceptual and empirical analyses. In particular, we verify the theoretical propositions. From the supply side of credit, wholesalers are more likely to be credit-constrained when (1) they operate as a non-corporation; and (2) they have less collateral to back up the loans. From the demand side of credit: wholesalers are more likely to be discouraged from applying for loans when (1) their operations are relatively small; and (2) when their effective application cost is high, which is posited as depending on information and transaction costs that without official support depend largely on social networks of relatives and friends in the same or related businesses.

These findings have important policy implications for the smooth operations of agricultural wholesalers in China and elsewhere. Notably, since there are twice as many discouraged borrowers who need credit as there are rationed applicants for loans who also need credit, policy makers should pay particular attention to how to offset the factors affecting mostly small to medium-size wholesalers. Thus, to improve agricultural wholesalers' access to credit, researchers and policy makers should address the roles of both the demand and supply sides in generating credit constraints.

Because corporations are less likely to be credit-constrained than non-corporations, self-employed wholesalers and partnerships need to be transformed into corporations in order to smooth risks and improve productivity, which will result in an increase in industrial concentration and in the efficiency of the agricultural wholesale sector in China. Second, changes in what qualifies as collateral for agricultural wholesalers are necessary. Third, based on our results, smaller-sized wholesalers are more likely to be credit constrained. Therefore, policy makers and financial institutions could further provide loans aimed at smaller-sized wholesalers to improve credit access. Such loans with government subsidies are currently being provided to selected wholesalers. Finally, social capital can help potential borrowers obtain more loan information, which lowers the possibility of self-rationing, therefore, it is essential to build social networks for agricultural wholesalers by means like business associations. To sum up, since agricultural wholesalers play an important role in stimulating market performance and transactions, policy makers and financial institutions should focus on innovation of loan mechanisms to effectively eliminate credit constraints among agricultural wholesalers. Based on the results of this study, size matters. A possible course of action would be to provide loans to expand operations. Besides mergers and acquisitions in the agricultural wholesaler sector in the long run, the fostering of credit cooperatives or association could aggregate operations to attain the credit access of larger operations.

Due to its scope, this study has limitations that can open avenues for further research. One limitation is that the survey only included agricultural wholesalers but did not include financial institutions, such as microcredit companies and banks. Given the supply side of credit, these institutions can provide a key insight into innovations and policy changes to mitigate credit constraints for agricultural wholesalers. Another limitation may be not fully dealing with endogeneity of credit constraints. A different methodology, such as randomized controlled trials, may control more properly for agents facing credit constraints. In addition, even though we were able to identify and quantify some impacts of credit constraints and generate some of evidence on the micro-foundations through which credit operates, we did not explicitly quantify any welfare effects or cost-benefits of using various policy tools for addressing credit constraints. Our results and the few policy actions proposed are, therefore, suggestive. Further work can focus on quantifying these effects. Finally, whether the results of this study can be extended to other countries or agricultural institutions beyond those in our sample is a question that awaits further analysis. 


\section{Acknowledgements}

This work was supported by the National Science Foundation of China [No. 71633005], the Fundamental Research Funds for the Central Universities, and Program for Young Innovative Research Team in China University of Political Science and Law [No. 20CXTD10]. Part of the work reported here was conducted when Lifang $\mathrm{Hu}$ was a visiting Ph.D. student at the University of Connecticut from Renmin University of China, under sponsorship of the China Scholarship Council. The authors are solely responsible for the views and content of the paper.

\section{References}

Akoten, J.E., Y. Sawada and K. Otsuka. 2006. The determinants of credit access and its impacts on micro and small enterprises: the case of garment producers in Kenya. Economic Development and Cultural Change 54(4): 927-944.

Alem, M. and J.J. Elias. 2018. Allocating production risks through credit cum insurance contracts: the design and implementation of a fund for small cotton growers to access market finance. International Food and Agribusiness Management Review 21(2): 237-248.

Ali, D.A., K. Deininger and M. Duponchel. 2014. Credit constraints and agricultural productivity: evidence from rural Rwanda. Journal of Development Studies 50(5): 649-665.

Banerjee, A. and E. Duflo. 2014. Do firms want to borrow more? Testing credit constraints using a directed lending program. Review of Economic Studies 81: 572-607.

Berkowitz, J. and M.J. White. 2004. Bankruptcy and small firms' Access to credit. The RAND Journal of Economics 35(1): 69-84.

Boucher, S.R., C. Guirkinger and C. Trivelli. 2009. Direct elicitation of credit constraints: conceptual and practical issues with an application to Peruvian agriculture. Economic Development and Cultural Change 57(4): 609-640.

Briggeman, B.C., C.A. Towe and M.J. Morehart. 2009. Credit constraints: their existence, determinants, and implications for U.S. farm and nonfarm sole proprietorships. American Journal of Agricultural Economics 91(1): 275-289.

Carter, M.R. and P. Olinto. 2003. Getting institutions 'right' for whom? Credit constraints and the impact of property rights on the quantity and composition of investment. American Journal of Agricultural Economics 85(1): 173-186.

Cox, D. and T. Jappelli. 1993. The effect of borrowing constraints on consumer liabilities. Journal of Money, Credit and Banking 25(2): 197-213.

Crook, J. 1996. Credit constraints and U.S. households. Applied Financial Economics 6(6): 477-485.

Fafchamps, M. and B. Minten. 1999. Relationships and traders in Madagascar. Journal of Development Studies 35(6): 1-35.

Fafchamps, M., E. Gabre-Madhin and B. Minten. 2003. Increasing returns and market efficiency in agricultural trade. Journal of Development Economics 78(2): 406-442.

Gabre-Madhin, E.Z. 2001. The role of intermediaries in enhancing market efficiency in the Ethiopian grain market. Agricultural Economics 25(2-3): 311-320.

Gao, Y., B. Liu, L. Yu, H. Yang and S. Yin. 2019. Social capital, land tenure and the adoption of green control techniques by family farms: evidence from Shandong and Henan provinces of China. Land Use Policy 89: 104250.

Hu, L., R.A. Lopez and Y. Zeng. 2019. The impact of credit constraints on the performance of agricultural wholesalers. Applied Economics 51(35): 3864-3875.

Jappelli, T. 1990. Who is credit constrained in the U.S economy? Quarterly Journal of Economics 105(1): 219-234.

Kersten, R., J. Harms, K. Liket and K. Maas. 2017. Small firms, large impact? A systematic review of the SME finance literature. World Development 97: 330-348.

Kon, Y. and D.J. Storey. 2003. A theory of discouraged borrowers. Small Business Economics 21(1): 37-49. 
McKinnon, R.I. 1973. Money and capital in economic development. Brookings Institution, Washington, DC, USA.

Ministry of Commerce of China. 2014. 2013 statistical analysis report of agricultural wholesale market industry. Ministry of Commerce of China, Beijing, China.

Narayanan, S. 2016. The productivity of agricultural credit in India. Agricultural Economics 47(4): 399-409.

Olomola, A.S. 2014. Determinants of agro-dealers' participation in the loan market in Nigeria. International Food and Agribusiness Management Review 17(3): 65-84.

Petrick, M. 2004. A microeconometric analysis of credit rationing in the polish farm sector. European Review of Agricultural Economics 31(1): 77-101.

Shaw, E.S. 1973. Financial deepening in economic development. Oxford University Press, New York, NY, USA.

Stiglitz, J.E. and A. Weiss. 1981. Credit rationing in markets with imperfect information. American Economic Review 71(3): 393-410.

Van de Ven, W.P. and B. Van Praag. 1981. The demand for deductibles in private health insurance. Journal of Econometrics 17(2): 229-252.

Yu, X., D. Abler and Y. Zeng. 2009. Contractual arrangements by traders in Chinese agricultural wholesale markets. Presented at 2009 International Association for Agricultural Economists (IAAE) Conference, Beijing, China.

Zhao, J. and P.J. Barry. 2014. Effects of credit constraints on rural household technical efficiency: evidence from a city in Northern China. China Agricultural Economic Review 6(4): 654-668. 
